\title{
INTERNATIONAL LEGAL INSTRUMENTS IN THE FIELD OF BIOETHICS AND THEIR IMPACT ON PROTECTION OF HUMAN RIGHTS
}

DOI: 10.36740/WLek202007144

\author{
Viktor V. Horodovenko ${ }^{1}$, Vitalii M. Pashkov' ${ }^{2}$, Larysa G. Udovyka ${ }^{1}$ \\ 'ZAPORIZHZHIA NATIONAL UNIVERSITY, ZAPORIZHZHIA, UKRAINE \\ 2POLTAVA LAW INSTITUTE OF YAROSLAV MUDRIY NATIONAL LAW UNIVERSITY, POLTAVA, UKRAINE
}

\begin{abstract}
Introduction: A rapid development of biomedicine, genetics, pharmacology, transplantation and biotechnology has posed a number of problems to humanity, in particular, with regard to human rights protection in healthcare. These problems solution requires considering the achievements and propositions of biology, medicine, ethics and law. International legal standards in the field of bioethics are of significance in development of national states regulations on bioethics and biotic legislation.

Aim: To investigate the impact of international legal instruments in the field of bioethics on protection of human rights.

Materials and methods: In the research the international legal instruments and documents in the field of healthcare and bioethics were used. Civilizational, axiological, dialectical, systemic and comparative legal methods as well as systematization, analysis and synthesis were decisive in the research process.

Conclusions: Legal instruments in the field of biomedical technologies (directives and regulations) are mainly advisory by nature. In many cases, the problems arising in biotechnology are resolved through establishment and involvement of national supervision bodies: councils (commissions, committees) in bioethics as well as courts. An important role in protection of human rights in the field of biotechnology is played by the ECHR the decisions of which are dynamic, based on the Convention and consideration of national legislations. At the same time, a number of problems remain unresolved because of constant development of biomedical technologies, necessity to take into account the latest achievements and discoveries as well as all types and methods of applying of genetic engineering to humans. In general, insufficient attention is paid to the problems of medical biotechnologies application both at the international and national levels.
\end{abstract}

KEY WORDS: bioethics, biolaw, biomedicine, medical law, international medical law, international document

Wiad Lek. 2020;73(7):1554-1560

\section{INTRODUCTION}

Rapid development of biomedicine, genetics, pharmacology, transplantation and biotechnology opens fundamentally new possibilities for improving the quality of life and its duration, but at the same time it may result in unpredictable and contradictory consequences. On the one hand, these possibilities include artificial insemination, surrogacy, transplantation, stem cell treatment, etc., but on the other - there are also the problems of human cloning, euthanasia, experiments on humans and animals. The complex and multidimensional nature of these problems requires attention of various sciences with their achievements and propositions, in particular, biology, medicine, ethics, law and psychology. It is also extremely important to have a common understanding of the international community problems, to establish the international legal principles and standards in the field of bioethics which must be the basis for national regulations.

It is quite natural that the issues that arise in genetics, pharmacology, transplantation and biotechnology are increasingly subject to legal regulation at the international level. The legal provisions enshrined in international regulatory and legal instruments with regard to bioethics are becoming a part of national legislations and affecting protection of human rights.

\section{THE AIM}

The article aims to study the international legal instruments in the field of bioethics and their impact on protection of human rights.

\section{MATERIALS AND METHODS}

In order to achieve the goal a set of general and special scientific approaches as well as the methods of social and legal phenomena cognition were used, namely: civilizational and axiological methods - to study the value basis of bioethics; dialectical method - to identify the relationship and interaction of international, regional and national legislations in the field of healthcare and bioethics; systemic method - to investigate protection of human rights in the field of bioethics; comparative legal method - to analyze foreign experience of legal regulation and protection of human rights in bioethics. Their use in correlation and complementarity enabled us to achieve the goal of this 
research, to provide a comprehensive understanding of the research subject, scientific reliability and credibility of researches' results.

\section{RESULTS AND DISCUSSION}

In modern science the issues related to the progress of genetics, genomics, pharmacology, transplantology, biotechnology and cloning mainstreamed not only scientific discussions within the relevant sciences but also caused a number of problems in understanding of legislation and legal regulation. This consequently resulted in the establishment of biolaw, biojurisprudence and biotic legislation. Scientists share the view that the object of bioethics is human intervention into the natural processes of treatment both environment and human nature. The bioethics subject is the related moral problems that arise - the problems of mankind survival and maintenance of life on the planet [1, p. 22]. Therefore, bioethics exists rather as an incessant field of ethical, religious, psychological and legal problems, constantly expanding and becoming more complicated and having no simple and unambiguous solutions, than as a scientific discipline with a clear subject and generally accepted common language. Within bioethics there are a lot of legal problems primarily related to promotion and protection of human rights in healthcare, the right to privacy, the right to information, etc.

In the 1990s at the intersection of philosophy of law, theory of law, constitutional, administrative, civil and international law on the one hand and medicine and bioethics - on the other, biojurisprudence started to take shape. The latter is considered by modern scientists as the newest scientific area aimed to maintain and legally protect human life in relation to an intensive development of biomedicine. The principle of the highest value of life of man as a biosocial being forms the basis of biojurisprudence.

The analysis of scientific sources shows that the term "biojurisprudence" was introduced into science by Roman Tokarczyk, a Polish scientist, Professor at Maria Curie-Sklodowska University in Lublin. The scholar presented his main propositions and key ideas in his writings "Biojurisprudence. Foundations of Law for theTwenty-First Century" (2008) [2] and "The Rights to Birth, Life and Death: Foundations of Biojurisprudence" (2012) [3]. The Tokarczyk concept of biojurisprudence grounds on the interpretation of the essence of understanding the deepest meaning of law - "life" (of human beings, society and other living beings) and in a generalized form is realized in the following propositions: life, primarily human life, determines the deepest meaning of the subject matter of jurisprudence and law; the current development of biological sciences (biotechnology) is based on artificial intervention in the natural processes of life; the trends in biotechnology, bioengineering and biomedicine indicate a gradual expansion of the scope of their artificial intervention in the natural processes of life; the consequences of artificial interference in natural processes of life are exposed to various appraisals, especially religious, moral and legal ones; a variety of appraisals of artificial interference in natural processes of life is the basis for the conviction that not everything that is technically possible must be morally permissible; it is difficult to overestimate and even predict all the serious consequences of artificial interference in natural processes of life [3]. The above ideas and propositions were further developed by $\mathrm{M}$. Weiss, $\mathrm{K}$. Wolska-Lipiec, R. Tokarczyk (Poland), M. Kashintseva, O. Merezhka, V. Plavich, P. Rabinovich, R. Stefanchuk, S. Stetsenko, M. Medvedeva (Ukraine), V. Kruss, M. Maleina, M. Matuzova, G. Romanovsky, V. Salnikov (Russia), etc.

Biomedical achievements and discoveries are the major factor which constantly encourages scientific research of philosophical, legal, general theoretical and sectoral problems in the field of bioethics. Recognition of the biotechnology and biomedicine achievements at the international level has intensified the need for legal regulation of public relations in healthcare and bioethics as well as establishment of biotic legislation and biojurisprudence.

Despite the fact that the term "biojurisprudence" appeared in the 1990s, the problems in this area and attempts to resolve them legally have a much longer history. The establishment of international legal instruments which significantly affect protection of human rights in the field of bioethics has lasted for more than 70 years since 1946 . For the first time, in the Constitution of the World Health Organization it was declared that "The enjoyment of the highest attainable standard of health is one of the fundamental rights of human being without distinction of race, religion, political belief, economic or social condition". The health of all peoples is a fundamental factor in achieving peace and security and depends on the closest cooperation of individuals and states. The achievement of any state in improvement of health and health care is valuable for everyone [4]. These and other provisions of the WHO Constitution laid the foundation for international medical law, national law and legislation in the field of bioethics of most developed states.

The history of the legal instrument's establishment in the field of bioethics shows that the most high-profile debate on the bioethics problems by the international community first took place in 1946-1947 in Nuremberg. It was dedicated to the medical human subject research conducted during World War II, namely the forced medical research, murders of war prisoners for the August Hirtanatomical collection, forced euthanasia, forced sterilization, etc. One of the consequences of this process was the creation of the Nuremberg Code, which regulated the conduct of scientific experiments and human subject research as well as introduction of ethical standards for scientists engaged in medical experiments. The Code said that for conduction of human subject research the voluntary consent of the human subject is essential. This voluntary consent should be based on full awareness of the human subject after providing him with full information about the nature, duration, purpose of the experiment, methods and means of its realization, all alleged inconveniences and dangers of the experiment, possible consequences for physical and 
mental health of the subject, which may arise as a result of his participation in the experiment. Even though the requirements of this Code only became moral imperatives and were not binding they were then embodied in a number of national legislations in the field of medical research on human subjects. In addition, the Code encouraged the mankind and individual states to obtain scientific knowledge about the maintenance of human health.

During $20^{\text {th }}$ century a row of international legal instruments of an integrated nature were adopted at the international level, which along with the right to life and health laid the basis for settlement of biotic issues (the Universal Declaration of Human Rights adopted in 1948, the International Covenant on Economic, Social and Cultural Rights adopted in 1966). Among the three groups of international medical documents distinguished in modern science [5], namely: 1) acts and documents concerning the issues of the healthcare sector reform (the Declaration of Alma-Ata, the Ljubljana Charter, etc.); 2) acts and documents, which provide for the legal status of participants in healthcare relationship (the Declaration of Lisbon on the Rights of the Patient, the European Charter of Patients' Rights, etc.), the international legal instruments, which lay the grounds in the field of bioethics, should be referred to group 3, that is, the acts and documents with regard to specialized issues in medicine and healthcare (the Declaration on Euthanasia, the Declaration of Sydney on human death, the Principles for the Protection of Persons with Mental Illness and the Improvement of Mental Health Care, the Universal Declarationon theHuman Genome and Human Rights, etc.).

Among the international instruments in bioethics which provide for the ethical standards and conduct of scientific research on humans and are based on the principle of personal autonomy special attention should be paid to the Declaration of Helsinki of the World Medical Association on Ethical Principles for Medical Research Involving $\mathrm{Hu}$ man Subjects [6]. The document was adopted by the 18th WMA General Assembly held in Helsinki (Finland), in July 1964. Subsequently, the document was repeatedly revised and amended, namely: at the 29th WMA General Assembly, Tokyo (Japan), October 1975; the 35th WMA General Assembly, Venice (Italy), October 1983; the 41st WMA General Assembly, Hong Kong, September 1989; the 48th WMA General Assembly, Somerset West (South Africa), October 1996; the 52nd WMA General Assembly, Edinburgh (Scotland), October 2000; the 53rd WMA General Assembly, Washington, DC (the USA), 2002 (explanatory note to \$29); the 55th WMA General Assembly, Tokyo (Japan), 2004 (explanatory note to $\$ 30$ ); the 59th WMA General Assembly, Seoul (South Korea), October 2008.

The establishment of biolaw and biomedical legislation was influenced by a number of international instruments adopted by various entities, primarily the United Nations (UN), the World Medical Association (WMA), the United Nations Educational, Scientific and Cultural Organization (UNESCO), the Council of Europe (COE), the Parliamentary Assembly of the Council of Europe (PACE), the Committee of Ministers of the Council of Europe, the European
Parliament (EP). In addition, the bioethical principles and standards are contained in the bioethical international, regional and national legal documents of specialized international and regional integration organizations, in the national legislations of different countries.

In terms of rule-making the most important among them are the following: the UN International Convention on the Elimination of All Forms of Racial Discrimination of 21 December 1965, the UN Convention on the Elimination of All Forms of Discrimination Against Women of 18 December 1979, the UN Convention on the Rights of the Child of 20 November 1989, the UN Convention on Biological Diversity of 5 June 1992, the UN Standard Rules on the Equalization of Opportunities for Persons with Disabilities of 20 December 1993). In addition, a number of international instruments with regard to bioethics issues were adopted by the UN specialized agencies, in particular, the Food and Agriculture Organization of the United Nations (FAO) and the World Health Organization (WHO).

The World Medical Association (WMA) - the Declaration of Helsinki of the World Medical Association on Ethical Principles for Medical Research Involving Human Subjects adopted in 1964 and amended in 1975, 1989, 1996 and 2000; the Declaration of Lisbon on the Rights of the Patient adopted in 1981 [7].

The UNESCO [8] -The UNESCO Recommendation on the Status of Scientific Researchers of 20 November 1974, the UNESCO Declaration on Race and Racial Prejudice of 27 November 1978, the Universal Declaration on Bioethics and Human Rights of 1978. The UNESCO Bioethics Programme was initiated in 1993, with the creation of the International Bioethics Committee (IBC), which is the first and only Bioethics Committee with the global scope of activities and expert membership. The UNESCO programme is tasked to reveal the most significant bioethics issues for different regions of the world in order to identify and implement appropriate strategies that would promote reflection on ethical and legal issues at the regional and sub regional levels, as well as to strengthen national capacities and international cooperation in the field of bioethics [9]. Subsequently, the UNESCO Declaration on the Responsibility of the Present Generations Towards Future Generations of 12 November 1997, the UNESCO Universal Declaration on the Human Genome and Human Rights of 11 December 1997, the UNESCO Universal Declaration on Cultural Diversity of 2 November 2001 were adopted. In 2005, the UNESCO International Bioethics Committee has developed the Universal Declaration on Bioethics and Human Rights [10].

The Council of Europe (COE) - The Convention for the Protection of Human Rights and Dignity of the Human Being regarding the Application of Biology and Medicine: Convention on Human Rights and Biomedicine, adopted by the Council of Europe in 1997 (entered into force in 1999), and Additional Protocols thereto) [11]. The Convention sets out the fundamental principles regarding patients' rights, namely equitable access to medical care, protection of the right to informed consent, confidentiality and the 
right to acquire information. These principles are binding for the states that've ratified the Convention.

The Parliamentary Assembly of the Council of Europe (PACE) - Recommendation 934 (1982) on Genetic Engineering, Recommendation 1046 (1986) on the Use of Human Embryos and Foetuses for Diagnostic, Therapeutic, Scientific, Industrial and Commercial Purposes, Recommendation 1100 (1989)on the on the Use of Human Embryos and Foetuses in Scientific Research, the Resolution on Cloning (1998), the Directive 98/44/ECon Legal Protection of Biotechnological Inventions (1998), etc. [12].

The Committee of Ministers of the Council of Europe -the Resolution (78) 29 on Harmonisation of Legislations of Member States Relating to Removal, Grafting and Transplantation of Human Substances (1978), the Recommendation No. 92 on the Use of DNA Analysis in the Criminal Justice System (1992), the Convention on Human Rights and Biomedicine (European Convention on Bioethics) (1996) [13].

The European Parliament - the Resolution on Artificial Insemination "in vivo" and "in vitro" (1989), the Resolution on Ethical and Legal Problems of Genetic Engineering (1989). [14]

The activities of the Council for International Organizations of Medical Sciences (CIOMS) also deserve our consideration. The CIOMS has adopted a number of instruments - the International Ethical Guidelines for Health-related Research Involving Human Subject of 1982, amended in 1993 and 2002. In addition, in 2002 Active Citizenship Network in collaboration with public organizations from different EU countries developed the European Charter of Patients' Rights [15] which clearly and fully interpreted the rights of patients.

Among the ideas and provisions of the specified legal instruments in the context of human rights protection there are the provisions of special significance which provide for protection of dignity and identity of the person, guarantee everyone, without discrimination, respect for their integrity and other rights and fundamental freedoms with regard to application of biology and medicine, the prevalence of human being interests over sole interests of society or science. The provisions also set out the need to comply with relevant professional obligations and standards for any medical intervention, including research; the need for a person's voluntary informed consent to medical intervention; protection and respect for private and family life in collection, transmission and storage of personal medical data; prohibition of discrimination against a person on the basis of his genetic heritage; prohibition of commercial use of the human body. At the same time, it should be noted that the above instruments largely reflected the intensive theoretical research of bioethical problems of scientific experiments, and unfortunately, they were not legally binding.

The Convention for the Protection of Human Rights and Dignity of the Human Being with regard to the Application of Biology and Medicine can be considered the first international binding instrument in the field of bioethics. The Convention was adopted by the Council of Europe in
Oviedo, on 4 April 1997 and entered into force in 1999. Subsequently, the Convention was supplemented by Additional protocols as of 12 January 1998, 24 January 2002 and 25 January 2005[16].

The activities of the European Court of Human Rights have a significant impact on the development of bioethics, national and international legislation in the field of health protection and biotic issues. The analysis of the ECHR practices [17] gives the grounds to identify several groups of human rights, in relation to which the issues of bioethics were raised, namely:

1) reproductive rights, prenatal diagnosis [Draon v. France, 2006] [18], the right to a legal abortion [Tysiącv. Poland, 2007] [19]; [R. R.v. Poland, 2011] [20], [Zv. Poland, 2013] [21], [Dubská and Krejzováv. the Czech Republic, 2014] [22], [Kosaitė-Čypienè and others v. Lithuania, 2019] [23]; 2) artificial insemination [Evans v. the UnitedKingdom, 2007] [24], [Dickson v. the UnitedKingdom, 2007] [25], [S.H and Others v. Austria, 2011] [26], [Costa and Pavanv. Italy, 2013] [27], [Parrillov. Italy, 2015] [28], [Foulon and Bouvet v. France, 2016] [29];

3) euthanasia [Pretty v. the United Kingdom, 2002] [30], [Haas v. Switzerland, 2011] [31], [Jack Nicklinson v. the United Kingdom and Paul Lamb v. the United Kingdom, 2015] [32], [Koch v. Germany, 2012] [33], [Gross v. Switzerland, 2014] [34];

4) the patient's consent to medical examination or treatment: a) general issues regarding consent [Hoffmann v. Austria, 1993] [35], [Arskayav. Ukraine, 2014] [36], [Petrovav. Latvia, 2014] [37], [M.S. v. Croatia (no. 2), 2015] [38], [Lambert and others v. France, 2015] [39], [Bataliny v. Russia, 2015] [40], [Fernandes de Oliveira v. Portugal, 2019] [41]; b) consent to pelvic examination [Juhnke v. Turkey, 2008] [42], [Salmanoğlu and Polattaşv. Turkey, 2009] [43], [Konovalova v. Russia, 2014] [44]; c) consent to sterilization [V.C v. Slovakia, 2011] [45], [Y.Y. v. Turkey, 2015] [46], [S.V. v. Italy, 2018] [47], [Bogdanovav. Russia, 2015] [48];

5) ethical issues concerning HIV and other life-threatening diseases: a) threat of eviction [Francisco J. Arcila Henaov. the Netherlands, 2003] [49], [N. v. the United Kingdom, 2008] [50], [Kiyutin v. Russia, 2011] [51]; b) isolation of patients [Enhorn v. Sweden, 2005] [52]; c) confidentiality [Colak and Tsakiridisv. Germany, 2009] [53], [I.B. v. Greece, 2013] [54], [Y. v. Turkey, 2015] [55]; d) preventive measures / access to treatment [Claesv. Belgium, 2013] [56], [Savinov v. Ukraine, 2015] [57], [Catalin Eugen Micu v. Romania, 2016] [58], [Karpylenko v. Ukraine, 2016] [59], [Blokhinv. Russia, 2016] [60];

6) storage of fingerprints, cell samples and/or DNA by authorities: [Gillbergv. Sweden, 2012] [61], [M.K. v. France, 2013] [62], [Antonio Peruzzo v. Germany and Uwe Martens v. Germany, 2013] [63], [Elbertev. Latvia, 2015] [64];

7) the right to access information on biological origin: [AndrzejKlocek v. Poland, 2012] [65], [Grönmark v. Finland, 2010] [66], [Kruškovićv. Croatia, 2011] [67], [Kautzor v. Germany, 2012] [68], [Ahrenz v. Germany, 2012] [69]. 
In its decisions the ECHR repeatedly refers to international instruments in the field of bioethics including the Convention for the Protection of Human Rights and Dignity of the Human Being with regard to the Application of Biology and Medicine adopted in Oviedo on 4 April 1997, in particular, in the following cases: [Cyprus v. Turkey, 2001][70], [Vo v. France, 2004] [71], [Evans v. the United Kingdom, 2007] [24], (the complaint was declared inadmissible, article 5 of the Oviedo Convention was cited); [Costa and Pavan v. Italy, 2013] [27], [Lambert and others v. France, 2015] [39], [Bataliny v. Russia, 2015] [40]. In addition, the ECHR considers the activities of the Council of Europe in this area, in particular in the following cases: [Parrillov. Italy, 2015] [28], [Paradiso and Campanelliv. Italy, 2015] [72].

Special attention in the context of human rights protection should be paid to the issues of transplantation of human organs and tissues [73] and the use of reproductive technologies [74].

The analysis of the ECHR practices shows that most often the court deals with the issues of reproductive rights, artificial insemination, consent of the patient to medical examination and treatment, the right to access information on the biological origin, euthanasia, ethical aspects in relation to HIV, storage of biological material by public authorities. Such cases primarily fall within the scope of Article 8, as well as Articles 2,3,5, 6. With the further rapid development of biotechnology, the applications regarding gene therapy, stem cell research and treatment as well as cloning will be the subjects of consideration. The ECHR draws attention to a considerable discretion of states in a number of issues (in particular, the issue of adequate and timely medical care in the framework of prenatal research (A.K. v. Latvia) [75]; the need to maintain a fair balance between the interests of society on the one hand, and protection of the right to respect privacy - on the other (Draonv. France, 2006) [18]. The European Court of Justice has repeatedly noted that the concept of "inviolability" is unclear, especially when positive obligations of the state depending on the circumstances are concerned. Therefore, in assessing the positive obligations of the state the need to respect the rule of law - a fundamental principle of democratic state is crucial) (Carbonara and Ventura v. Italy, 2000) [76]. Respect for the rule of law requires that national law provide legal protection against public authorities' interference in the rights guaranteed by the Convention (Hasan and Chaush v. Bulgaria, 2000) [77]. Special attention should be paid to the fact that the ECHR emphasizes that the Convention is aimed at ensuring rather real and valid rights than theoretical and illusory ones (Airey v. Ireland, 1979) [78].

\section{CONCLUSIONS}

Summarizing the above stated, we should note that at the international level there are many international legal instruments of an integrated nature, which, along with the human right to life and health, lay the basis for settlement of biotic issues. At the same time, especially in the field of biotechnology most legal instruments are of a regional character. The main law-makers in this area are the UNESCO, WHO, COE and EU. The legal instruments in the field of biomedical technologies (directives and regulations) are mainly advisory by nature. Directive $98 / 44$ concerning legal protection of biotechnological inventions is an exception. Comparing the experience of legal regulation in the field of biotechnology in foreign countries we can conclude that there are significant differences in the regulation of medical biotechnology, existence of general, abstract and inaccurate provisions. Italy has the most stringent legislation (which prohibits all ethically unacceptable types of medical biotechnology); the most liberal legislation is that of the UK (it provides for permission for therapeutic cloning and the use of embryonic stem cells from any source). Therapeutic cloning is also legally permitted in Belgium, Denmark and Switzerland. In many cases the problems arising in the field of biotechnology are resolved through the establishment and activities of national supervision bodies: councils (commissions, committees) on bioethics, in courts. An important role in protection of human rights in the field of biotechnology is played by the ECHR, with the decisions being dynamic, based on the Convention and, at the same time, taking into account national legislations. At the same time, some problems remain unresolved because of the constant development of biomedical technologies, the need to take into account the latest achievements and discoveries, all types and methods of applying genetic engineering to humans. In general, insufficient attention is paid to the problems of medical biotechnologies application both at the international and national levels.

\section{REFERENCES}

1. Pustovit S. V. Global'naja biojetika: stanovlenie teoriii praktiki (filosofskij analiz) [Global Bioethics: Formation of Theory and Practice (Philosophical Analysis)]. Pustovit S. V., ed. Kyiv: Arktur-A; 2009. (in Ukraine).

2. Tokarczyk R. A. Biojurisprudencja: podstawy prawa dla XXI wieku [Biojurisprudence. Foundations of Law for the Twenty-First Century]. Tokarczyk R. A., ed. Lublin: Wydawnictwo Uniwersytetu Marii CurieSklodowskiedj; 2008. (in Poland).

3. Tokarczyk R. Prawa narodzin, zycia i smierci. Podstawy biojurysprudencji [The Rights toBirth, Life and Death: Foundations of Biojurisprudence]. Tokarczyk R., ed. Warsaw: Wolters Kluwer Polska; 2012. (in Poland)

4. Charter of the World Health Organization: Principles, [Online], available at:http://www.who.int/about/mission/ru/(Accessed 20 November 2019) (in Russian).

5. Horodovenko, V.V., Pashkov, V.M., Udovyka L.G. "Protection of Patients' Rights in the European Court of Human Rights", Wiad. Lek. 2018; 71(6): 1200-1206.

6. WMA Declaration of Helsinki - Ethical Principles for Medical Research Involving Human Subjects, [Online],available at: https://zakon.rada.gov. ua/laws/show/990_005(Accessed 16 November 2019) (in Ukrainian).

7. WMA Declaration of Lisbon on the Rights of the Patient, [Online], available at:https://www.wma.net/policies-post/wma-declaration-of-lisbonon-the-rights-of-the-patient/(Accessed 1 December 2019).

8. United Nations Educational, Scientific and Cultural Organization (UNESCO). International Bioethics Committee (IBC), [0nline],available at: https://en.unesco.org/themes/ethics-science-and-technology/ibc (Accessed 2 December 2019).

9. Henk ten Have. The activities of UNESCO in the Area of Ethics. Kennedy Institute of Ethics Journal, 2006; 16(4): 333-351, [Online], available at: http://www.unesco.org/new/fileadmin/MULTIMEDIA/HQ/SHS/pdf/ KIEJ-2006.pdf(Accessed 1 December 2019). 
10. United Nations Educational, Scientific and Cultural Organization (UNESCO). Universal Declaration on Bioethics and Human Rights, 19 October, 2005, [Online], available at: http://portal.unesco.org/en/ ev.php-URL_ID=31058\&URL_D0=D0_TOPIC\&URL_SECTION=201. html(Accessed 1 December 2019).

11. Council of Europe. Treaty Office - Convention for the Protection of Human Rights and Dignity of the Human Being with regard to the Application of Biology and Medicine (1997), [Online], available at: https://www.coe.int/en/web/conventions/full-list/-/conventions/ rms/090000168007cf98 (Accessed 1 December 2019).

12. Parliamentary Assembly (PACE) - Council of Europe, [Online], available at:http://assembly.coe.int/nw/Home-EN.asp(Accessed 2 December 2019).

13. Council of Europe - Bioethics, [Online], available at: https://www.coe. int/en/web/bioethics/home (Accessed 2 December 2019).

14. Information Project "European Parliament", [Online], available at: https://europarlamentti.info/ru/Evropeyskiy-parlament/(in Russian) (Accessed 3 December 2019).

15. European Commission - European Charter of Patients' Rights, [Online],available at:https://ec.europa.eu/health/ph_overview/ co_operation/mobility/docs/health_services_c0108_en.pdf(Accessed 3 December 2019).

16. Convention for the Protection of Human Rights and Dignity of the Human Being with regard to the Application of Biology and Medicine: Convention for Human Rights and Biomedicine (4 April, 1997), [0nline],available at: https://zakon.rada.gov.ua/laws/show/994_334(in Ukrainian) (Accessed 3 December 2019).

17. European Court of Human Rights. Research Report - Bioethics and the case-law of the Court, [0nline], available at: https://www.echr.coe.int/ Documents/Research_report_bioethics_RUS.pdf(in Russian) (Accessed 3 December 2019).

18. Case of Draon v. France, 21 June 2006, [Online],available at: http:// hudoc.echr.coe.int/eng?i=001-75905 (Accessed 4 December 2019).

19. Case of Tysiąc v. Poland, 24 September 2007, [Online], available at: http://hudoc.echr.coe.int/eng?i=001-79812(Accessed 4 December 2019).

20. Case of R. R. v. Poland, 28 November 2011, [Online], available at:http:// hudoc.echr.coe.int/eng?i=001-104911(Accessed 4 December 2019).

21. Case of Zv. Poland, 13 February 2013,[0nline], available at:http://hudoc. echr.coe.int/eng-press?i=001-114521(Accessed 4 December 2019).

22. Case of Dubská and Krejzová v. the Czech Republic, 11 December 2014, [Online], available at: http://hudoc.echr.coe.int/eng/?i=001-148632 (Accessed 4 December 2019).

23. Case of Kosaitė-Čypienè and others v. Lithuania, 04 September 2019,[0nline], available at: http://hudoc.echr.coe.int/eng?i=001193452(Accessed 4 December 2019).

24. Case of Evans v. the United Kingdom, 10 April 2007,[Online], available at :http://hudoc.echr.coe.int/eng?i=001-80046(Accessed 4 December 2019).

25. Case of Dickson v. the United-Kingdom, 04 December 2007, [Online], available at: http://hudoc.echr.coe.int/eng?i=001-83788(Accessed 4 December 2019).

26. Case of S.H and Others v. Austria, 03 November 2011, [0nline], available at: http://hudoc.echr.coe.int/eng?i=001-107325(Accessed 5 December 2019).

27. Case of Costa and Pavan v. Italy, 11 February 2013,[Online], available at: http://hudoc.echr.coe.int/eng?i=001-112993(Accessed 5 December 2019).
28. Case of Parrillo v. Italy, 27 August 2015, [Online], available at: http:// hudoc.echr.coe.int/eng?i=001-157263 (Accessed 5 December 2019).

29. Case of Foul on and Bouvet v. France, 21 July 2016,[0nline], available at: https://www.echr.coe.int/Documents/FS_Surrogacy_ENG.pdf (Accessed 5 December 2019).

30. Case of Pretty v. the United Kingdom, 29 July 2002, [Online], available at: http://hudoc.echr.coe.int/eng?i=001-60448 (Accessed 5 December 2019).

31. Case of Haas v. Switzerland, 20 June 2011, [0nline], available at: http:// hudoc.echr.coe.int/eng?i=001-102940 (Accessed 5 December 2019).

32. Case of Jack Nicklinson v. the United Kingdom and Paul Lamb v. the United Kingdom, 23 June 2015, [0nline], available at: http://hudoc. echr.coe.int/eng?i=001-156476 (Accessed 5 December 2019).

33. Case of Koch v. Germany, 19 July 2012,[0nline], available at: http:// hudoc.echr.coe.int/eng?i=001-112282 (Accessed 5 December 2019).

34. Case of Gross v. Switzerland, 30 September 2014,[0nline], available at: http://hudoc.echr.coe.int/eng?i=001-146780 (Accessed 5 December 2019).

35. Case of Hoffmann v. Austria, 23 June 1993,[Online], available at:http:// hudoc.echr.coe.int/eng?i=001-57825(Accessed 5 December 2019).

36. Case of Arskaya v. Ukraine, 05 February 2014,[0nline], available at: http://search.ligazakon.ua/I_doc2.nsf/link1/S0000617.html (Accessed 5 December 2019).

37. Case of Petrova v. Latvia, 24 June 2014, [Online], available at: http:// hudoc.echr.coe.int/eng?i=001-144997 (Accessed 5 December 2019).

38. Case of M.S. v. Croatia (No. 2), 19 February 2015,[Online], available at: http://hudoc.echr.coe.int/eng?i=001-152259 (Accessed 5 December 2019).

39. Case of Lambert and others v. France, 05 June 2015,[0nline], available at: http://hudoc.echr.coe.int/eng?i=001-155352 (Accessed 5 December 2019).

40. Case of Bataliny v. Russia, 23 July 2015,[0nline], available at: https:// ru.scribd.com/document/275280948/Case-of-Bataliny-v-Russia (Accessed 5 December 2019).

41. Case of Fernandes de Oliveira v. Portugal, 31 January 2019, [Online], available at: http://hudoc.echr.coe.int/eng?i=001-189426(Accessed 5 December 2019).

42. Case of Juhnkev.Turkey, 13 May 2008,[0nline], available at:https://hudoc. echr.coe.int/app/conversion/pdf/?library=ECHR\&id=003-23490422534815\&filename $=003-2349042-2534815 . p d f \& T I D=$ thkbhnilzk (Accessed 5 December 2019).

43. Case of Salmanoğlu and Polattaş v.Turkey, 17 June 2009, [Online], available at: http://hudoc.echr.coe.int/app/conversion/ pdf $/$ ?library $=E C H R \& i d=001-91777 \&$ filename $=001-91777$. pdf\&TID=ihgdqbxnfi (Accessed 5 December 2019).

44. Case of Konovalova v. Russia, 09 0ctober 2014,[0nline], available at: http://hudoc.echr.coe.int/eng?i=001-146773 (Accessed 5 December 2019).

45. Case ofV.C v. Slovakia, 08 November 2011, [0nline], available at: http:// hudoc.echr.coe.int/eng?i=001-107364 (Accessed 5 December 2019).

46. Case of Y.Y. v. Turkey, 10 March 2015, [Online], available at: https://hudoc.echr.coe.int/eng-press\#\{\%22itemid\%22: [\%22003-5032376-6183620\%22]\} (Accessed 5 December 2019).

47. Case of S.V. v. Italy, 11 0ctober 2018, [0nline], available at:https:// laweuro.com/?p=5095(Accessed 5 December 2019).

48. Case of Bogdanova v. Russia, 10 June 2015, [0nline], available at: https:// tgeu.org/wp-content/uploads/2015/07/Bogdanova-v-Russia_thirdparty-intervention-FINAL.pdf (Accessed 5 December 2019). 
49. Case of Francisco J. ArcilaHenaov. the Netherlands, 24 June 2003, [Online], available at: https://www.globalhealthrights.org/wpcontent/uploads/2013/02/ECtHR-2003-Arcila-Hena0-v-Netherlands. pdf (Accessed 5 December 2019).

50. Case of N. v.the United Kingdom, 27. May 2008, [Online], available at: http://hudoc.echr.coe.int/eng?i=001-86490 (Accessed 5 December 2019).

51. Case of Kiyutin v. Russia, 10 March 2011, [Online], available at: https:// www.hr-dp.org/files/2013/09/11/CASE_OF_KIYUTIN_v._RUSSIA_. pdf(Accessed 5 December 2019).

52. Case of Enhorn v. Sweden, 25 January 2005, [0nline], available at: https://www.globalhealthrights.org/wp-content/uploads/2014/04/ Enhorn-v. -Sweden.pdf (Accessed 5 December 2019).

53. Case of Colak and Tsakiridis v. Germany, 5 March 2009, [Online], available at:https://www.globalhealthrights.org/wp-content/uploads/2015/11/ CASE-OF-COLAK-AND-TSAKIRIDIS-V.-GERMANY.pdf (Accessed 5 December 2019).

54. Case of I.B. v. Greece, 3 October 2013, [0nline], available at: http:// hudoc.echr.coe.int/eng?i=001-127055 (Accessed 5 December 2019).

55. Case of Y. v. Turkey, 24 April 2015, [0nline], available at: file:///C:/Users/\%D0\%90\%D0\%B4\%D0\%BC\%D0\%B8\%D0\% BD\%D0\%B8\%D1\%81\%D1\%82\%D1\%80\%D0\%B0\%D1\%82\%D0\%B E\%D1\%80/Downloads/003-5032376-6183620\%20(2).pdf (Accessed 5 December 2019).

56. Case of Claes v. Belgium, 10 April 2013, [Online], available at: http:// hudoc.echr.coe.int/fre?i=001-115981 (Accessed 5 December 2019).

57. Case of Savinov v. Ukraine, 22 October 2015, [Online], available at: https://zakon.rada.gov.ua/laws/show/974_b22 (Accessed 5 December 2019).

58. Case of Catalin Eugen Micu v. Romania, 12 January 2016, [0nline], available at:https://swarb.co.uk/catalin-eugen-micu-v-romania-echr12-jan-2016/(Accessed 5 December 2019).

59. Case of Karpylenko v. Ukraine, 11 February 2016, [0nline], available at: http://hudoc.echr.coe.int/eng?i=001-160431 (Accessed 5 December 2019).

60. Case of Blokhin v. Russia, 23 March 2016, [0nline], available at: http:// hudoc.echr.coe.int/eng?i=001-128047 (Accessed 6 December 2019).

61. Case of Gillberg v. Sweden, 03 April 2012, [Online], available at: http:// hudoc.echr.coe.int/eng?i=001-110144 (Accessed 6 December 2019).

62. Case of M.K.v. France, 18 April 2013, [Online], available at: http://hudoc. echr.coe.int/eng?i=001-119075 (Accessed 6 December 2019).

63. Case of Antonio Peruzzo v. Germany and Uwe Martens v. Germany, 04 June 2013,[0nline], available at: http://hudoc.echr.coe.int/ fre?i=001-121998 (Accessed 6 December 2019).

64. Case of Elberte v. Latvia, 15 January 2015, [Online], available at: http:// hudoc.echr.coe.int/eng?:=001-150234 (Accessed 6 December 2019).

65. Case of AndrzejKlocek v. Poland, 27 April 2010, [Online], available at: https://www.bailii.org/eu/cases/ECHR/2010/720.html (Accessed 6 December 2019).

66. Case of Grönmark v. Finland, 6 0ctober 2010, [0nline], available at: http://hudoc.echr.coe.int/app/conversion/pdf/?library=ECHR\&id=00199828\&filename $=001-99828 . p d f \& T I D=$ thkbhnilzk (Accessed 6 December 2019).
67. Case of Kruškovićv. Croatia, 21 June 2011, [0nline], available at: http:// hudoc.echr.coe.int/eng?i=001-105197 (Accessed 6 December 2019).

68. Case of Kautzor v. Germany, 22 March 2012, [Online], available at: http:// hudoc.echr.coe.int/eng-press?i=001-109809 (Accessed6 December 2019).

69. Case of Ahrens v. Germany, 22 March 2012, [Online], available at: http:// hudoc.echr.coe.int/eng?i=001-109815 (Accessed 8 December 2019).

70. Case of Cyprus v. Turkey, 10 May 2001, [Online], available at: http:// hudoc.echr.coe.int/eng?i=001-59454 (Accessed 8 December 2019).

71. Case of Vo. v. France, 08 July 2004, [Online], available at:http://hudoc. echr.coe.int/eng?i=001-61887(Accessed 8 December 2019).

72. Case of Paradiso and Campanelli v. Italy, 27 January 2015, [0nline], available at: https://www.echr.coe.int/Documents/Press_Q_A_ Paradiso_and_Campanelli_ENG.pdf (Accessed 8 December 2019).

73. Pashkov V.M., Golovanova I.A., Noha P.P. (2016), "Principle of serviceability and gratuitousness in transplantation?", Wiad. Lek., 2016; 69(3 II): 565-568.

74. Pashkov V.M., Lyfar A. (2018), “Assisted reproductive technologies: the problems of legal enforcement",Wiad. Lek., 2018; 71 (5): 1066-1070.

75. Case of A.K. v. Latvia, 24 June 2014, [Online], available at: http://hudoc. echr.coe.int/eng?i=001-145005 (Accessed 8 December 2019).

76. Case of Carbonara and Ventura v. Italy, 30 May 2000, [0nline], available at: https://files.pca-cpa.org/pcadocs/bi-c/1.\%20Investors/4.\%20 Legal\%20Authorities/CA299.pdf (Accessed 10 December 2019).

77. Case of Hasan and Chaush v. Bulgaria, 26 0ctober 2000, [Online], available at: http://hudoc.echr.coe.int/eng?i=001-58921 (Accessed 10 December 2019).

78. Case of Airey v. Ireland, 090 ctober 1979 , [0nline], available at: https:// hudoc.echr.coe.int/eng\#\{\%22itemid\%22:[\%22001-57420\%22]\} (Accessed 10 December 2019).

\section{ORCID and contributionship:}

Viktor V. Horodovenko: 0000-0001-6002-4192 A,B,E

Vitalii M. Pashkov: 0000-0001-9489-7768 ${ }^{A, D, F}$

Larysa G. Udovyka: 0000-0001-9260-4474 B,E

\section{Conflict of interest:}

The Authors declare no conflict of interest.

\section{CORRESPONDING AUTHOR}

\section{Vitalii M. Pashkov}

Poltava Law Institute of Yaroslav Mudryi

National Law University, Poltava, Ukraine

e-mail:v.pashkov26.06@ukr.net

Received: 21.12.2019

Accepted: 19.05.2020

A - Work concept and design, B - Data collection and analysis, C - Responsibility for statistical analysis, D-Writing the article, $\mathbf{E}$-Critical review, $\mathbf{F}$ - Final approval of the article 